\title{
Learning Lesson Study in Improving Accounting Learning Results
}

\author{
Ijah Mulyani Sihotang \\ Accounting Education, University of Muhammadiyah Sumatera Utara (UMSU), Medan, Indonesia \\ ijahmulyani@umsu.ac.id
}

\begin{abstract}
This study aims to analyze the learning of Accounting with Lesson Study Activities and describe how Accounting learning outcomes by applying Lesson Study-based learning. This research is motivated by the difficulty of students in studying accounting. This is indicated by the low student accounting learning outcomes. The research subjects were 38 students of Accounting Education in Semester II FKIP UMSU. The approach of this research is a descriptive approach, the research procedure is carried out by implementing Lesson Study activities namely Plan, Do and See. The research instrument was in the form of tests and observation sheets. The data analysis technique is descriptive analysis technique. The results showed that accounting learning outcomes were still in the low category with an average score of 70.7, if a range of values was included in the $C / B$ category, while the observations related to students' learning activities fall into the unfavorable category because most students have not maximized in classroom learning activities. If a range of values is entered into the $C / B$ category, while the results of observations related to student learning activities fall into the unfavorable category because most students have not been maximal in classroom learning activities. Individual values indicate better results with a mean count of 80.9
\end{abstract}

Keywords : lesson study; leaning result; accounting

\section{Introduction}

Accounting courses are compulsory subjects for the Accounting Education Study Program, with emphasis on Cognitive aspects and Psychomotor aspects. As a compulsory subject, this course must be understood, mastered so that it can be implemented in the world of work and business. Based on the results of observations in class, accounting courses including courses are difficult because most of the educational backgrounds of students come from non-IPS majors during high school. Therefore the task of the lecturer must prepare for the learning so that the learning objectives can be maximally achieved. Learning planned in this study is Lesson Study based learning. . why should Lesson Study?, because Lesson Study is a learning activity whose purpose is to improve the quality of learning. Herawati (3: 2011) stated that the implementation of Lesson Study was conducted collaboratively between teachers and lecturers, starting from the design of learning, observing the implementation of learning and reflecting on the implementation of learning. Lesson-based learning is in line with the demands of 21st century learning. According to I Wayan Redhana (2019) Development of 21 st century skills in all learning, including chemical learning, must be carried out by all educators. The development of these skills cannot be done without a planned and systematic effort, but must be done intentionally by designing the right target. There are 4 skills demanded in this learning known as 4C namely Communication (Communication), Critical Thinking and Problems (Critical Thinking and Problem Solving), Collaboration (Collaboration), Creativity and Innovation (Creativity and Innovation). These four skills, if associated with National Education goals, are very adequate because the National Education goals set forth in article 3 state that national education functions to develop capabilities and form dignified national character and civilization in order to educate the nation's life, aiming at developing potential 
students to become man of faith and devotion to God Almighty, noble, healthy, knowledgeable, capable, creative, independent, and a citizen of a democratic and responsible state.

\section{Review of Literature}

Learning Approaches There are two types of teacher-centered and student-centered. The student-centered learning paradigm is no longer in line with the times. In the digital age now, sometimes more students and the first is compared to the teacher because of the ease in getting information. Learning teacher-centered approaches whose emphasis is on memorization, lectures do not make students' creative thinking abilities develop. Sudarisman stated that realizing the complexity of the challenges in the future, the UNESCO education field commission (Commission Education for the "21" Century) recommended 4 pillars of education that could be used as educational foundations including: Learning to know, which is learning to know by exploring knowledge from various information; Learning to do, which is learning to do an action or express ideas; Learning to be, which is learning to identify yourself and adapt to the environment; Learning to live together, which is learning to live a life together and community that are interdependent, so that they can compete in a healthy manner and work together and be able to respect others.

These four pillars of education are very relevant to student-centered learning and in line with 21 st century learning. 21st century learning has 4 skills, namely communication skills, critical thinking skills, collaborative skills and creative and innovative skills. These four skills have been able to accommodate the demands of life in the 21st century today. According to Zubaidah "The main goal of 21st century learning is to build individual learning abilities and support their development into lifelong, active learners, independent learners". A smart student is not necessarily successful if the student is not able to communicate with his environment, unable to solve his life problems by thinking critically, not having creativity and innovating and not having the ability to collaborate with others. Schools as agents of change must be able to change the learning paradigm where teacher-centered shifts become student-centered. Watch the picture of learning shifts of the 21st century, Ethics, 2016:

Table 1. $21^{\text {st }}$ century learning shift

\begin{tabular}{|l|l|}
\hline $\begin{array}{c}\text { Characteristics of the } \\
\text { 21st century }\end{array}$ & \multicolumn{1}{c|}{ Learning model } \\
\hline $\begin{array}{l}\text { Information (available } \\
\text { anywhere, anytime) }\end{array}$ & $\begin{array}{l}\text { Learning is directed at encouraging students to find out } \\
\text { from various sources of observation. }\end{array}$ \\
\hline $\begin{array}{l}\text { Computing (using a } \\
\text { machine faster) }\end{array}$ & $\begin{array}{l}\text { Learning is directed at being able to formulate problems } \\
\text { (ask questions) not only to solve problems (answer) }\end{array}$ \\
\hline $\begin{array}{l}\text { Automation (Reaching } \\
\text { out to routine work) }\end{array}$ & $\begin{array}{l}\text { Learning is directed to train thinking analysis (decision } \\
\text { making) rather than thinking mechanisms (routine) }\end{array}$ \\
\hline $\begin{array}{l}\text { Communication (from } \\
\text { anywhere, anywhere). }\end{array}$ & $\begin{array}{l}\text { Learning emphasizes the importance of collaboration and } \\
\text { collaboration in solving problems }\end{array}$ \\
\hline
\end{tabular}

The characteristics of the 21st century above force teachers to be able to create quality learning $21^{\text {st }}$ century learning teachers no longer act as givers of knowledge, but the emphasis is more on preparing students to have skills. Despite the current era of the digital era, it is not entirely the role of the teacher to be replaced by the four $21^{\text {st }}$ century characteristics mentioned above. The teacher must create varied learning with his pedagogic and professional knowledge. Teachers who vary learning that allows students to connect with the real world. 
Zubaidah, (2016) states that a teacher needs to master various fields, be proficient in pedagogy including innovation in teaching and learning, understanding the psychology of learning and having counseling skills, following developments on curriculum policies and educational issues, being able to utilize new media and technology in learning, and still apply values to the formation of good personality and character. $21^{\text {st }}$ century teacher.

Lesson Study began in Japan around the 1870s, known as Jugyokenkyu. developed by Japan International Cooperation Agency (JICA). Americans call it Lesson Study. Americans began to be interested in Lesson Study, when the 1996 International International Mathematics and Science Study (TIMSS) was held, the results of which were Japanese students received high rankings in mathematics. One of the alleged supporting factors is Jugyokenkyu. In Indonesia it is known as Learning. But this term is rarely used because it is more popular with the term Lesson Study. Herawaty (2011: 3) states that Lesson Study is a major form of improving the quality of learning and the development of teacher professionalism chosen by Japanese teachers. In the implementation of Lesson Study is carried out by the teacher in collaboration in terms of: Studying the curriculum and formulating learning objectives and development goals of students (developing life skills), Designing learning to achieve its objectives, Carrying out and observing a research Lesson, Learning to discuss learning that is reviewed and refine it and plan the next lesson.

Mahmudi, (2009) in more detail states that lesson study more fully can be interpreted as a collaborative process from a group of teachers to collectively: Identify learning problems that are felt by the teacher (one or a group of teachers), Planning steps - learning steps (as identified problem solving efforts), Carrying out learning carried out by one of the selected teachers (agreed), while other teachers observe the learning process, Evaluate the learning process that has been done, Improve learning planning based on the evaluation results, Carry out learning again, reevaluate the learning that has been carried out, and share (disseminate) the experiences and findings of the results of the evaluation to other teachers.

Lesson Study learning carried out by teachers in the classroom by involving relevant parties is carried out in the form of large activities. These activities can be more simply divided into 3 activities, namely Plan, Do and See. This can be seen in the following picture:

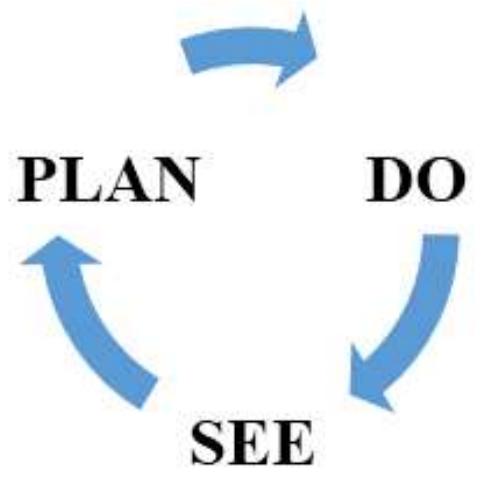

Picture 1. Stages of Lesson Study

Plan is the activity of planning starting from planning Determining student learning goals, Determining material must be understood / mastered by students, Arranging student learning steps, Adjusting learning steps with available time, Inventory of equipment needed for learning (learning assistance), learning devices, model teachers will carry out classroom learning. 
Do is carrying out learning and at the same time observing the implementation of this learning in the classroom. The implementation of observations is carried out together with the implementation of learning. Direct observation in the class carried out by the observer aims to be able to observe student behavior more specifically in the learning process. Usually the teacher can only observe the students' prominence whether the student is very active, smart or students who have more deficiencies.

See is doing a reflection to improve learning if it is considered still inadequate and planning learning in the next stage. Research conducted by Murtiani et al. (2012) classifies the level of ability of students at low, medium and high levels stating that student learning activities with the implementation of lesson-based learning can improve student learning activities and student learning outcomes. Lesson Study is not a model applied by teachers in class, but Lesson Study can be combined with other innovative learning so that learning is not monotonous so some teachers really like learning Lesson Study because there are so many benefits obtained by the teacher. Subadi $(2010,8)$ states that there are several benefits of Lesson Study, namely: The teacher can document the progress of his work, the teacher can obtain feedback from other members / communities and the teacher can publish and disseminate the final results of Lesson Study. For visionary teachers, they really want Lesson Study learning because based on the above benefits, they will provide great benefits for teachers in their ranks

\section{Methodology}

This study was conducted on Accounting Education Study Program students located in FKIP UMSU $2^{\text {nd }}$ grade A Accounting morning, on Wednesday, March 28, 2019. This type of research is experimental research, which is carried out in learning with lesson study activities as many as two meetings and learning methods what is applied is the recitation method. This study was an experimental study with a recitation method by applying lesson study activities. This research was carried out in three stages, namely: the initial stage, at this stage by analyzing the needs by analyzing the syllabus, analyzing the teaching material to be delivered in learning and forming lesson study groups, in this case the researcher involved eighth semester students (8) in implementing lesson learning study. The second stage is the implementation phase / data collection stage, at this stage the research data collection process is carried out by carrying out learning activities with lesson study activities. The lesson study learning steps include three stages, namely Plan, Do and See. Plan (Planning), in this planning phase, the time for implementing the action plan is determined (which is tasked with carrying out classroom learning), design Lesson (RPP) and giving direction (technical meeting) with the observer. Do (Implement), the implementation of learning is carried out in class as many as two meetings (2x150 minutes) The first meeting is carried out learning with adjusting journal material. The second meeting was assessed by a test. See (Observe). Observing activities are carried out in line with the implementation of lesson study learning, followed by reflection activities. Reflection activities are activities conveying the findings obtained about students during the implementation of the learning delivered by the observer. These findings will be used as material to follow up on the next activity. The third stage of the reporting phase, the reporting phase is to do data processing and compile reports. The instrument used in this study was to use tests and observation sheets obtained from the results of reflection. The data analysis technique of this research is descriptive analysis technique with steps to collect data, tabulate data, analyze data and conclude research data. 


\section{Discussion}

This study involved 10 observers whose task was to observe student learning activities which were divided into 5 (five) groups, each group observed by 2 (two) observers. The implementation of learning with the activity of lesson study is to see student learning outcomes that are associated with the student's learning activities, whether they learn and how they learn. Based on the results of the learning activity data obtained from observations, student learning activities can be seen in the following table:

Table 1. Findings of Student Learning Activities in Groups

\begin{tabular}{|c|c|}
\hline Group & Important Findings \\
\hline 1 & $\begin{array}{l}\text { 1. Between students in learning, only most students are serious in learning } \\
\text { 2. Lack of understanding of the answers to the questions given } \\
\text { 3. There is debate in solving problems } \\
\text { 4. Conducive learning conditions } \\
\text { 5. Make notes for things that are just known } \\
\text { 6. From } 7 \text { discussion group members there are people who make sure the } \\
\text { answers given can be justified } \\
\text { 7. There is a small part that focuses on personal activities } \\
\text { 8. Inactive group discussion activities }\end{array}$ \\
\hline 2 & $\begin{array}{l}\text { 1. Group collaboration is conducive } \\
\text { 2. There is only } 1 \text { person who is not active in discussions } \\
\text { 3. Look for answers by opening the book and cellphone } \\
\text { 4. The discussion group is very good } \\
\text { 5. Understanding the lack of questions }\end{array}$ \\
\hline 3 & $\begin{array}{l}\text { 1. The atmosphere in conducive learning } \\
\text { 2. Not all group members express their opinions } \\
\text { 3. Group members cannot work together well } \\
\text { 4. Only } 4 \text { people understand about the questions given } \\
\text { 5. Lack of cooperation in discussions } \\
\text { 6. During the discussion there were some who read wa } \\
\text { There are } 3 \text { people who do not understand the questions given at all }\end{array}$ \\
\hline 4 & $\begin{array}{l}\text { 1. Group cooperation is not conducive } \\
\text { 2. Students are more silent } \\
\text { 3. There is only } 1 \text { person working on the AJP question given } \\
\text { 4. Settlement of the problem given is only resolved by } 2 \text { people } \\
\text { 5. There are } 2 \text { people engrossed in playing cellphones that have no connection } \\
\text { with learning materials }\end{array}$ \\
\hline 5 & $\begin{array}{l}\text { 1. When learning takes place conducive conditions } \\
\text { 2. At the beginning of a conducive discussion over time, it is getting bored } \\
\text { 3. There are } 3 \text { silent people without contributions in the group } \\
\text { 4. The solution to the problem is mostly solved by one person } \\
\text { 5. There are difficult questions to understand } \\
\text { 1. Answer hesitantly, finally the answer was replaced }\end{array}$ \\
\hline
\end{tabular}

And group learning results can be seen in the following table: 
Table 2. Group Value Data

\begin{tabular}{|c|c|}
\hline Groups & Score \\
\hline 1 & 80 \\
\hline 2 & 60 \\
\hline 3 & 100 \\
\hline 4 & 30 \\
\hline 5 & $\mathbf{8 3 , 3}$ \\
\hline
\end{tabular}

Individual learning result data in the Adjustment Journal material as follows:

Table 3. Data on Accounting Learning Result

\begin{tabular}{|c|c|c|}
\hline No & Student Name & Score \\
\hline 1 & Bella Grasefa & 82 \\
\hline 2 & Sintya Apriani & 81 \\
\hline 3 & Dhea Defri Ayumi & 79 \\
\hline 4 & Furida Halawiyah & 82 \\
\hline 5 & Rafiqoh Nisa & 80 \\
\hline 6 & Nuri Sriwidari & 85 \\
\hline 7 & Regha Nasiyah & 85 \\
\hline 8 & Rizkinah Lubis & 76 \\
\hline 9 & Rosalina & 75 \\
\hline 10 & Debi Nadilah & 78 \\
\hline 11 & Dina Fitriana Chan & 74 \\
\hline 12 & Retno Wulandari & 77 \\
\hline 13 & Yumia Anggun Sari & 69 \\
\hline 14 & Nurul Amaliyah & 95 \\
\hline 15 & Sanimah Wahyuni & 92 \\
\hline 16 & Kerryn Maulia & 80 \\
\hline 17 & Yunila Sari & 84 \\
\hline 18 & Retno Tri Ningsih & 88 \\
\hline 19 & Wahidunnisa Putri & 92 \\
\hline 20 & Zita Namira Oktiviani & 88 \\
\hline
\end{tabular}




\begin{tabular}{|c|l|c|}
\hline No & \multicolumn{1}{|c|}{ Student Name } & Score \\
\hline 21 & Intan Andriani & 68 \\
\hline 22 & Irma Yunita & 72 \\
\hline 23 & Desi Rahmadahni & 62 \\
\hline 24 & Andre Sirait & 60 \\
\hline 25 & Rina Lestari & 77 \\
\hline 26 & Anggun Laila Sari & 75 \\
\hline 27 & Muwaffaq Fadhil Syah & 88 \\
\hline 28 & Sangkot Arifrahman & 88 \\
\hline 29 & Mahsyuri Tanjung & 82 \\
\hline 30 & Putri Handayani & 85 \\
\hline 31 & Anggun Sintya & 90 \\
\hline 32 & Dinda Safitra & 85 \\
\hline 33 & Putri Enggrasia & 90 \\
\hline 34 & Inneke Rahma Ulfa & 87 \\
\hline & Total & $\mathbf{2 7 5 1}$ \\
\hline & Total Average & $\mathbf{8 0 . 9 1 1 7 6 4 7}$ \\
\hline
\end{tabular}

If it is associated with data on student learning activeness with group learning outcomes, it can be described as follows:

The first Group gets learning outcomes with a value of 80, if seen from activeness in learning, it can be seen that learning is still conducive, even though there are most group members who do not focus when discussing problem solving, debate in solving exciting problems and certainty over group answers. answer, this condition leads the group to get a value of 80 .

The second group obtained 60 learning outcomes, when viewed from learning activity, it was shown that group cooperation was conducive, there was only 1 person who was not active in discussions, looking for answers by opening books and cell phones, discussion groups were very good, understanding the questions that were lacking. Learning conditions fall into the good category, but understanding the subject matter is lacking so that the problem solving is difficult, but this group does not want to ask other groups or the lecturers so that they are only busy with their own problems.

The third group obtained 100 learning outcomes, when viewed from learning activeness, it was shown that the condition of this group was not much different from the other groups, but there were four people who contributed to solving the problem even though 3 people were not active at all. so this group of three cooperates in a bad group. the value obtained is the result of group work that has good abilities but not from maximum group work.

The fourth group obtained 30 learning outcomes, if seen from the learning activeness of this group, it was obtained an illustration that activeness of group learning was not good 
because of seven group members only two people were actively discussing in solving the remaining problems engrossed with personal activities not related to learning for example playing HP, WA etc.

The fifth group obtained 83.3 learning outcomes, if seen from the learning activeness of this group, it was illustrated that when learning about conducive conditions, the group talked too much, there were four active people from seven people, three of whom sat quietly. despite the conditions of such groups, the situation of this group was saved by four people in this group who were active and possessed good abilities

Broadly speaking, the group learning outcomes with lesson study can be said to be still not maximal because the average calculated value obtained is 70.7. This value is still in the form of group values and the future will be assessed individually, because the emphasis of this research is still on student learning activities observed.

Based on the results of observations directly by the observer, it can be stated that the learning activeness of students by looking at how students learn and associated with the mean learning outcomes of the group still shows a condition that is not maximal

From the table above, it can be seen that the learning outcomes of students with lesson study learning with the recitation method (assignment) obtained an average of 80.9, although there were still students who scored $<74$ as many as 6 people $(17.6 \%)$. The remaining 28 people $(82.4 \%)$ got a value of $\geq 75$. This indicates that student learning outcomes individually are better when compared to group learning, the average value of which is 70.7 .

\section{Discussion}

Based on the results of the study, it can be concluded that learning carried out with Lesson study activities gives a real picture of how students learn in the classroom so that the general picture of student learning activities is still low. this was marked by the unfavorability of students when learning with discussion in solving problems, there were still passive students in discussions, there were still students who were busy with personal activities such as playing cellphones without having anything to do with learning, discussion activities that were still done individually and vice versa. students who take their duties seriously. group learning outcomes obtained are still in the moderate category with a calculated average value of 70.7 . this value is included in the low category and inidividual learning results obtained an average value of 80.9 .

\section{Acknowledgment}

This research was conducted at FKIP Muhammadiyah University, North Sumatra. Thank you to the Dean of FKIP Muhammadiyah University of North Sumatra for contributing to providing a place for the implementation of this research, and also no less useful for the University of Muhammadiyah North Sumatra who have provided financial assistance for the smooth running of this study with research on trade agreements with number: 113 / II . 3-AU / UMSU-LP2M / C / 2019

\section{References}

Ali Mahmudi, (2009). Mengembangkan Kompetensi Guru Melalui Lesson Study, Jurnal Forum Kependidikan FKIP, volume 28, nomor 2 Maret 2009, hal 84-89. UNY 
Cipto Subadi, 2010, Lesson Study Bebasis PTK suatu Model Pembinaan Menuju Guru Proesional. BP KIP-UMS

Etistika Yuni Wijaya, Dwi Agus Sudjimat, Amat Nyoto (2016), Transformasi Pendidikan Abad 21 sebagai tuntutan Pengembangan Sumber Daya Manusia di Era Global, Proseding Seminar Nasional Pendidikan Matematika 2016, UNIKAMA, Malang.

Herawati Susilo et al, (2011). Lesson Study Berbasis Sekolah Guru Konservati menuju guru inovatif, Bayumedia Publishing, Malang.

J.M. Tejawati, (2011). Peningkatan Kompetensi Guru Melalui Lesson Study: Kasus Di Kabupaten Bantul, Jurnal Pendidikan dan Kebudayaan, vol. 17, no. 4 hal 480-489

Murtiani et al, (2012), Penerapan Pendekatan Contextual Teaching and Learning (CTL) Berbasis Lesson studidalam Meningkatkan Kualitas Pembelajaran Fisica di SMA negeri Kota Padang, Jurnal Penelitian Pembelajaran Fisika (2012) 1-21

Oemar Hamalik. (2009). Proses Belajar Mengajar. Bandung: Bumi Aksara.

Rusman. 2015. Pembelajaran Tematik Terpadu, Teori Praktik dan Penilaian. Grafindo:Jakarta

Sardiman. 2006. Interaksi dan Motivasi Belajar-Mengajar. Jakarta : PT. Raja Grafindo Persada

Suciati Sudarisman (2015). Memahami hakikat dan karakteristik pembelajaran biologi dalam upaya menjawab tantangan abad 21 serta Optimalisasi implementasi kurikulum 2013, Florena, Jurnal Biologi dan Pembelajaran, 2 (1), 29-35

Zubaidah, (2016). Keterampilan Abad Ke-21: Keterampilan Yang Diajarkan Melalui Pembelajaran, Seminar Nasional Pendidikan dengan tema "Isu-isu Strategis Pembelajaran MIPA Abad 21, tanggal 10 Desember 2016. STKIP Persada Khatulistiwa Sintang, Kalimantan Barat. 